\title{
Delivering Low Income Housing-Role of Access to Land and Credit in Gujarat, India
}

\author{
Jay Mittal1, H. M. Shivanand Swamy² \\ ${ }^{1}$ Auburn University, Auburn, USA \\ ${ }^{2}$ CEPT University, Ahmadabad, India \\ Email: jay.mittal@auburn.edu, shivanand.swamy@gmail.com
}

Received 22 July 2014; revised 20 August 2014; accepted 11 September 2014

Copyright $@ 2014$ by authors and Scientific Research Publishing Inc.

This work is licensed under the Creative Commons Attribution International License (CC BY).

http://creativecommons.org/licenses/by/4.0/

(c) (i) Open Access

\begin{abstract}
Housing, particularly for the poor and marginalised, is a complex urban problem that occupies centre-stage in present-day development issues. Access to housing is influenced by two major factors-land, and finance. Absence of either (or both) of these results in mushrooming of high density, environmentally insanitary living areas commonly referred to as slums. The poor and vulnerable sections increasingly struggle to secure adequate quality of shelter, because of their inability to access land at affordable rates and finance to be built. As the inflow of the poor from rural to urban is, by now, accepted as inevitable, providing housing and economic opportunities for these would have to form part and parcel of any sustainable urban development strategy. In the state of Gujarat, formal housing supply is unable to meet even a fraction of the housing demands in urban areas. Thus a mix of private and informal sector housing has emerged in the past few decades. During the 1990s, the involvement of NGOs in facilitating access of the poor to housing finance also became increasingly significant. This paper presents a critical review of housing delivery systems in urban Gujarat with an emphasis on the poor. A schematic design for delivery of land and access to housing finance for poor households has also been presented.
\end{abstract}

\section{Keywords}

Urban Housing, Land Servicing, Housing Finance, Micro Credit, Low Income Households

\section{Introduction}

Gujarat state, located in the western part of the country is one of the leading industrial states of Indian union. With over 37 percent of population residing in the urban areas, the state is second most urbanized state in the country. Over 50 percent of state's workforce is engaged in non-agricultural activities and accounts for over 70 percent of the state's income (Directorate of Economics \& Statistics, Government of Gujarat, 1999). With these 
changes, the state is fast transforming into a predominantly urban state, hence the urban focus in this paper.

Housing is one of the basic necessities of life and is one of the three most essential commodities along with food and clothing. Despite, considerable efforts over successive five year plans, the housing problem continues to be daunting in terms of rapid growth of slums and unauthorized colonies, deficiencies in water, sanitation, and other basic services, spiralling prices and rents of land and housing etc. Besides food, housing is the largest budget item for most households in developing countries. An average family spends almost 20 to 30 percent of their monthly household income either as rents or as instalments for the repayment of housing loans or on maintenance.

Housing remains relatively inaccessible to the poor and marginalised sections, resulting in the mushrooming of high density, environmentally insanitary living areas commonly referred to as slums. The poor and vulnerable sections increasingly struggle to secure adequate quality of shelter. Of the four components required in constructing a house: land, construction material, technology and finance, the present scheme of things lays emphasis on improved building construction technologies, materials and regulations. However, the issues related to access of low income households to finance and land suitable for housing at affordable prices have not been addressed adequately.

In the light of the above, this paper presents a critical review of housing delivery systems in urban Gujarat with an emphasis on poor. A schematic design for delivery of land and access to housing finance for poor households has also been presented.

\section{Gujarat: Urbanization Trends}

Gujarat has always been one of the most urbanized states in the country. Of the total state population of 50.1 Million $^{1}$, over 37 percent reside in 242 urban centres $^{2}$. The urban population share in 1991 was 34.5 percent. In line with the trends observed at the national level, a general decline in the rate of growth in population has been recorded both in urban as well as rural areas. However, the decline is much sharp in case of rural areas. Of the total increment in population during the period 1991-2001, 56.2 percent went to urban areas. During the period 1951-1961, the share was 20.3 percent, which increased to 35.9, 42.0 and 50.5 percent during the successive three decades. These trends are clear evidences of Gujarat transforming into a predominantly urban society. As per authors' forecasts, by the year 2020 about 40 million people constituting nearly 55 percent of the state population would be living in urban areas of Gujarat.

The Table 1 shows urbanization trends and decadal growth rates in Gujarat state from year 1901 to 2001.The urbanisation in Gujarat is largely characterized by intensification process rather than new town phenomena. The number of urban centres has declined from 264 in 1991 to 242 in 2001. This in essence implies expansion of

\begin{tabular}{|c|c|c|c|c|c|c|}
\hline Census Year & No. of Towns & Total Population & $\begin{array}{l}\text { Decadal Growth } \\
\text { Rate (Total) }\end{array}$ & $\begin{array}{c}\text { Urban } \\
\text { Population }\end{array}$ & $\begin{array}{c}\text { Decadal Growth } \\
\text { Rate (Urban) }\end{array}$ & Percent Urban \\
\hline 1901 & 166 & $9,094,748$ & - & $2,030,738$ & - & 22.33 \\
\hline 1911 & 155 & $9,803,587$ & 7.8 & $1,886,775$ & -7.1 & 19.25 \\
\hline 1921 & 166 & $10,174,989$ & 3.8 & $2,050,339$ & 8.7 & 20.15 \\
\hline 1931 & 172 & $11,489,828$ & 12.9 & 2,355,009 & 14.9 & 20.50 \\
\hline 1941 & 191 & $13,701,551$ & 19.2 & $3,259,955$ & 38.4 & 23.79 \\
\hline 1951 & $24 \mathrm{f}$ & $16,262,657$ & 18.7 & $4,427,896$ & 35.8 & 27.23 \\
\hline 1961 & 181 & $20,633,350$ & 26.9 & $5,316,624$ & 20.1 & 25.77 \\
\hline 1971 & 216 & $26,697,475$ & 29.4 & $7,496,500$ & 41.0 & 28.08 \\
\hline 1981 & 255 & $34,085,799$ & 27.7 & $10,601,653$ & 41.4 & 31.10 \\
\hline 1991 & 264 & $41,309,582$ & 21.2 & $14,246,061$ & 34.4 & 34.49 \\
\hline 2001 & 242 & $48,387270^{*}$ & 17.1 & $18,227,051^{*}$ & 27.9 & $37.67 *$ \\
\hline
\end{tabular}

Source: Census of India, 2001, provisional Results. *Excludes earthquake-affected areas where census 2001 could not be conducted.

\footnotetext{
${ }^{1}$ Includes Census of India estimates for Earthquake affected areas where census could not be conducted in the year 2001.

${ }^{2}$ The census of India defines urban areas as_all other places, which have a minimum population of 5000 people, at least 75 percent of the male working population engaged in non-agricultural and allied activities and has a density of at least 400 persons per sq km.
} 
existing large urban areas to include smaller urban centres and rural areas. As per the estimate, during 19811991, about 72 percent of urban growth is attributable to natural growth, 19 percent to net in-migration and another 9 percent to reclassification effect. The settlement structure has a wide base with six municipal corporations $^{3}$ on the top. The city of Ahmedabad is the largest Municipal Corporation city accommodating 35 million people (Census of India, 2001). Three Corporation cities, namely, Surat, Vadodara and Rajkot are million plus population cities. Bhavnagar and Jamnagar are two other corporation cities with population size of 510 thousand and 445 thousand respectively (Census of India, 2001). These six cities, together, accounts for over 50 percent of the urban population of the state. Because of the size of population and other activities, urban problems in general and the housing problem in particular get magnified in these cities. The remaining towns are classified by the Gujarat Urban Development Department, for the purpose of governance and resource allocation, based on the population size of 1981 in to four different classes. In all there are 9 Class-A, 32 Class-B, 44 Class-C and 58 Class-D towns ${ }^{4}$ totalling up to 143 towns. Remaining 93 settlements have been classified as urban areas by the Census department but still are governed by rural administrative institution. These are classified as "Others" in this paper.

\section{Status of Housing}

At the outset it is necessary to note that over the decades significant improvements in the housing conditions have taken place, a result of general economic progress and attempts by successive governments through various policy and programme measures. However, the status is far from satisfactory. This section outlines the urban housing condition based on available information. The detailed results of 2001 census are not available on housing related aspects; hence the discussion is based on 1991 census data. Extrapolation has been done wherever possible.

\subsection{Household Formation and Housing Supply Levels}

Key variables in determining housing situation are the rate of household formation and the supply response. Over last few decades, the household size has been decreasing at a faster rate. As per 1991 census, average household size in urban Gujarat is 5.3, which has decreased from 5.8 in 1971. However, occupancy rates have remained high at 5.6 persons per occupied house during 1981 and 1991. Evidences suggest that the situation has remained same during the period 1991-2001.

In terms of rate of supply, housing supply from the formal sector has lagged behind. The rate of formal housing construction in the country is about 3 dwelling units per 1000 population per year as against the required rate of 5. Annual supply of formal urban housing in Gujarat continues to be low at " 19 to 24 percent of the annual requirement” (General Administrative Department, Government of Gujarat, 2000; Directorate of Economics \& Statistics, Government of Gujarat, 1999).

\subsection{Vacancy Rates}

While on one hand there is a shortage of formal supply of housing (Lall, 1996), on the other, the vacancy rate in urban areas remain high. To enable mobility, moderate levels of vacancy rates are essential. In urban Gujarat, vacancy rate has risen from 11.47 percent in 1981 to 15.47 percent in 1991 (Census of India, 1971-1991). This could be related to the restrictive provisions of the Rent Control Act, 1947.

\subsection{Tenure}

Apparently, more and more number of households appears to opt to reside in their own houses. This trend is apparent in an increase in owner occupied houses from 51 percent in 1981 to 66 percent in 1991. This observation however has to be read with caution. On one hand, increasing vacancy rates could mean that few owners are ready to take the risk of letting out their property for rental purposes. While on the other hand, with limited supply options in the rental market, households are forced to share dwellings. This has been corroborated by the fact that the occupancy rates have remained high.

\footnotetext{
${ }^{3}$ Municipal Corporations are cities having 500 thousand populations.

${ }^{4}$ Population of Class-A cities $=$ more than 100 thousand people, Class-B $=50,000-100,000$, Class-C $=30,000-50,000$ and Class-D $=$ $10,000-30,000$ population.
} 
Two important factors discouraging rental market, the first relates to the provision of Rent Act under the prevailing law which is in favour of tenants. The fear of loosing property discourages owner to give property on rent.

The second relates to the Property Tax System, where as per the Act, local bodies are entitled to levy "Property Tax" which is levied as a proportion of ratable value on all the properties within its area of jurisdiction. In case of rented properties, annual rent is taken as ratable value which may be as high as 66 percent of the rent. Over and above this, Water charges and Conservancy Cess are also added to the tax. As a result, constructing houses for giving on rent as commercial proposition becomes totally unviable.

\subsection{Crowding}

As per 1991 Census, about 38 percent of urban households live in one-room houses. House size viewed along with family size depicts the situation to be worse. Nearly 49 percent households with family size of 3 to 5 members, live in single-room houses while another 30 percent live in dwellings with two or more rooms.

\subsection{Quality of Housing}

Scores of people continue to live in inhuman conditions caused by poor quality building materials and construction along with minimal access to infrastructure and services. The urban housing conditions with respect to the wall and roof material have been presented in Table 2. It is clear that overall housing condition in urban centres of the state has improved over the years in terms of quality of material used. With an increased percentage of houses having concrete roofs (from 31.6 percent in 1971 to 44.4 percent in 1991), and burned brick wall (from 45.2 percent in 1971 to 82.9 percent in 1991), the number of Pucca ${ }^{5}$-houses in the urban centres of the state has increased. However, one fourth of total housing stock is still built with substandard building materials like grass, leaves, reeds, thatch, mud etc.

\subsection{Basic Services}

Provision of potable water, safe sanitation and other minimum basic services are essential conditions for achieving good quality of life. Though, the situation is relatively better in Gujarat as compared to other states in the country, the gaps are significant. About 30 percent of urban households do not have tapped water supply within their own premises. There are still about 40 to 45 percent households without sanitation facilities (CEPT \& UD \& UH, 2000). The effects of inadequacies in water and sanitation facilities are evident in high rates of morbidity and infant mortality. In the industrial town of Jetpur, about 55 percent of the visits to medical facility are related to diseases attributed to environmental condition. Nearly a quarter of visits were made for water related diseases Swamy (2001).

\subsection{Slums}

Physically crowded developments comprising temporary and poor quality shelters; inadequacies in basic services and illegal or quasi-legal land tenure status get referred to as slums or squatter settlements. Slums are perceived as physical manifestations of urban poverty. Any effort to ameliorate physical conditions of slums would have to address the issue of urban poverty. The slum population in the state has increased from 1.88 million to an estimated 2.44 million in 1990. In larger cities one person among every four persons is a slum dweller. These

\begin{tabular}{|c|c|c|c|c|}
\hline \multirow[t]{2}{*}{ Type of Material } & \multicolumn{2}{|c|}{ Type of Roofing Material (Percent of Dwellings) } & \multicolumn{2}{|c|}{ Walling Material (Percent of Dwellings) } \\
\hline & 1971 & 1991 & 1971 & 1991 \\
\hline Kuccha $^{6}$ & 35.3 & 23.6 & 51.0 & 7.94 \\
\hline Semi Pucca & 31.3 & 28.22 & 3.7 & 7.88 \\
\hline Pucca & 31.6 & 44.4 & 45.2 & 82.95 \\
\hline All other Materials & 1.8 & 2.4 & 0.1 & 0.54 \\
\hline
\end{tabular}

Source: Census of India, 1991.

${ }^{5}$ Pucca is a local term used for permanent structures made of brick, concrete, wood etc.

${ }^{6}$ Kuchha is a local term used for temporary structures made of grass, leaves, reeds, thatch, mud etc. 
slums are located primarily on private and government owned land. Depending on the definition, the estimates of slum population vary between 11 to 23 percent in urban Gujarat.

\subsection{Shortages in Housing Sector}

The National Building Organization (NBO) estimated housing shortage in India in 1991 at about 31 million units-20.6 million in rural and 10.4 million in urban areas (Gujarat Social Infrastructure Development Board, 2000: p. 119). It was also estimated that by 1997, the housing shortage in the country would be about 13.66 million units, out of which 7.57 million units would be in the urban areas. More than 90 percent of this shortage is for the poor and the low-income category. An investment of about INRS 1,510,000 million ${ }^{7}$ would be required to bridge this deficit, but not more than 25 percent of this will flow from banks, financial institutions, Central and State Governments. Thus it is apparent that no significant headway can be achieved without massive participation of the private sector and popular sector.

Based on population estimates, assuming "a house a family", accounting for moderate vacancy and replacements rates and housing needs have been estimated. The difference between the housing need and present housing stock has been identified as present gap. Further, future requirements have also been estimated using the same approach (Table 3). The present gaps are essentially met with through increased occupancy rates of the existing stock. Though figures of private sector formal housing supplies at state level are not available, based on Ahmedabad Study, it is expected that private sector, formal supplies contribute to about 65 to 70 percent of the total requirement. The term formal is used to imply housing development generally meeting existing norms and standards stipulated by the local authority. Another 3 to 5 percent has been provided by the public sector agencies. The balance of 25 to 30 percent supplies has been made up by the informal/popular sector. These are essentially built with temporary material and referred to as "Slums".

\section{Housing Delivery Mechanisms}

Housing delivery mechanisms may broadly be analysed in terms of three broad segments. They are: a) Shelter Delivery System; b) Land Management System; and c) Housing Finance System. Indian housing supply system, to a large extent, followed socialist system, where government controls and public ownership dominates, to market-based housing systems (Mongia, 1996; Bertrand, 1991; Renauld, 1991). This is truer for affordable housing. An attempt has been made to describe these systems and identify the constraints limiting effectiveness of their performance.

\subsection{Shelter Delivery System}

Public, private as well as popular sectors, undertake the construction of housing for general public. The public sector participation is channelized through State Housing Board and Slum Clearance Board.

\subsection{Gujarat State Housing Board and Slum Clearance Board}

The Gujarat Housing Board (GHB) and Gujarat Slum Clearance Board (GSCB) are responsible for the public supply of housing. GHB is expected to cater to the lower income group and economically weaker section housing demand in Gujarat. However, with the intention to provide cross-subsidies to weaker sections of the society, GHB also constructs houses for middle and higher income groups. Of the total 152,000 houses built by GHB since it came into existence in 1960, about 30 percent were meant for middle and upper income groups. Annually, GHB constructs 3000 to 4000 houses. These houses are allotted to eligible individual households on "Hire-Purchase" basis. The agency, in addition to limited annual contribution in terms of dwellings constructed, is also best with multitude of problems. Among them, important ones are poor recovery rates, high overhead costs and non-availability of land. GSCB was established with the mandate to obtain land, provide services, build houses, and improve/clear slum areas. The Agency attempted to develop a few Sites and Service schemes without much success. Given its poor performance, the state government has shifted its responsibilities to GHB.

There is an imbalance in the scale of operations of GHB and GSCB on the basis of city-size and regional distribution. About 81 percent of houses constructed by GHB and 95 percent constructed by GSCB were confined to the six municipal corporation areas. Even among these, 70 percent houses supplied by GSCB and 60 percent

\footnotetext{
${ }^{7}$ One US Dollar is equivalent to 48 Indian Rupees as of November, 2001 exchange rates.
} 
Table 3. Housing stock and needs in Gujarat (million units).

\begin{tabular}{ccccccccccc}
\hline \multirow{2}{*}{ Urban Area type } & \multicolumn{3}{c}{ Stock } & \multicolumn{3}{c}{ Need } & \multicolumn{3}{c}{ Additional Requirement } \\
\cline { 2 - 10 } & $\mathbf{1 9 7 1}$ & $\mathbf{1 9 8 1}$ & $\mathbf{1 9 9 1}$ & $\mathbf{2 0 0 1}$ & $\mathbf{2 0 1 1}$ & $\mathbf{2 0 2 1}$ & Current Gap & $\mathbf{2 0 0 1 - 1 1}$ & $\mathbf{2 0 1 1 - 2 1}$ \\
\hline Municipal Corporation & 0.67 & 1.05 & 130 & 1.96 & 2.82 & 4.27 & 0.09 & 0.86 & 1.44 \\
Class-A & 0.16 & 0.22 & 0.31 & 0.42 & 0.56 & 0.76 & 0.01 & 0.14 & 0.20 \\
Class-B & 0.27 & 0.35 & 0.54 & 0.77 & 1.04 & 1.42 & 0.04 & 0.27 & 0.37 \\
Class-C & 0.16 & 0.19 & 0.25 & 0.33 & 0.42 & 0.55 & 0.01 & 0.90 & 0.13 \\
Class-D & 0.10 & 0.13 & 0.15 & 0.21 & 0.26 & 0.34 & 0.02 & 0.52 & 0.08 \\
Others & 0.14 & 0.20 & 0.32 & 0.47 & 0.66 & 0.93 & 0.01 & 0.20 & 0.27 \\
Total & $\mathbf{1 . 5 0}$ & $\mathbf{2 . 1 4}$ & $\mathbf{2 . 8 8}$ & $\mathbf{3 . 5 9}$ & $\mathbf{5 . 0 5}$ & $\mathbf{7 . 3 2}$ & $\mathbf{0 . 1 7}$ & $\mathbf{1 . 4 6}$ & $\mathbf{2 . 2 7}$ \\
\hline
\end{tabular}

Source: May 2000, base paper on housing, CEPT \& UD \& UH (CEPT \& UD \& UH, 2000).

supplied by GHB are in Ahmedabad alone. From the discussions above it is evident that the role of public sector agencies as providers of housing in general and specifically for the poor has not made any significant contribution and suggest the need for major restructuring of the agencies and their roles. The Table 4 shows the Eighth five-year plan's achievements by various housing unit type.

\subsection{Private Sector Housing}

Private sector developers are major contributors to the overall addition to the stock of housing. The developers build houses under the cooperative as well as non-trading corporations' laws. This gives them certain privileges in acquiring land. Access to cheap capital from State Housing Finance Cooperative Society was also an incentive, which also vanished during past decade. The housing built by private sector caters to wide range of income groups. However, bottom 30 percent does not have affordability to access these houses.

The housing built by private sector, though generally viewed as legal, has varying degrees of illegality built in the system. First of all, violations are made with regard to building bye laws in terms of margins, building additional floor area etc. Further, permission procedure is also not completely adhered to. The recent earthquake raised a lot of questions about the integrity of the construction sector putting the developer community under scrutiny.

The recent earthquake of January 26, 2001, has affected 15.7 million people in Gujarat. Total financial loss is estimated at 110 billion rupees in housing and other belongings. The damage has been extensive in the district of Kutchch and surrounding areas. A total of 269,382 houses were destroyed. Of these, 124,029 were "Semi-Pucca" and "Kutchha" houses. The number of damaged houses exceeds 500 thousand (GSDMA, 2001). The cities of Ahmedabad, Rajkot, Jamnagar and Bhavnagar also experienced prolonged ground shakes. In Ahmedabad city, a total of 69 multi-storied buildings collapsed taking a death toll of about 1000 persons.

The earthquake experience also appears to have brought in a shift in housing preferences of the city dwellers. The choice appears to have shifted from high and medium rise structures to low-rise structures. The demand for land and low rise housing structures has gone up suddenly. On the other hand, the prices of high-rise apartment flats, a common feature in most large cities of the state, have plummeted. To incorporate the essential requirements of earthquake safe buildings, the builders have to improve their construction methods as well as materials and technology. As a result, the cost of construction, as stated by local builders, has also risen by 30 to 40 percent. This is likely to increase the housing prices considerably.

\subsection{Informal Sector Housing}

The supply of housing by the formal sector, as described above, falls short of the total requirement. The poor, often through their self-help mode, meet with the balance. Most of the housing in these areas are built by individuals' themselves often using recycled building materials. Mehta D. and Mehta M. (1989) classify these settlements, as squatters and quasi-legal settlements. A community or an opportunist slumlord develops the squatter settlements on illegally appropriated land. The government and municipal lands are major target areas. In the case of quasi-legal settlements, the community or landlord purchases the land from owner, subdivides and then the individual develops. Rents are paid in all quasi-legal settlements. This land is, often reserved under some 
Table 4. Eighth five-year plan achievements by housing unit type (1992-1997).

\begin{tabular}{cccccc}
\hline Type Of House & $\mathbf{1 9 9 2 - 9 3}$ & $\mathbf{1 9 9 3 - 9 4}$ & $\mathbf{1 9 9 4 - 9 5}$ & $\mathbf{1 9 9 5 - 9 6}$ & $\mathbf{1 9 9 6 - 9 7}$ \\
\hline Site and Services & - & - & - & - & - \\
E.W.S & 361 & 1403 & 3202 & 2138 & 800 \\
L.I.G & 1373 & 2542 & 2203 & 2003 & 580 \\
Total & 1734 & 3945 & 5405 & 4141 & 1380 \\
\hline
\end{tabular}

Source: May 2000, base paper on housing, CEPT \& UD \& UH (CEPT \& UD \& UH, 2000).

public use or under the Urban Land Ceiling Act or land in long-standing dispute. The aim of the owner is to recover quickly, even if relatively less benefits from the land. The sale of land takes place outside the purview of standard procedures. Opportunistic slum lords also occupy such land and rent them after sub plotting. This informal sector housing caters to 30 percent of the urban population which is largely urban poor.

\subsection{Public Sector Initiatives to Improve Environmental Conditions}

Recognising the fact that slum clearance, as an approach was not workable, the states initiated Slum census in 1976. Further, the state initiated a series of programmes to provide basic amenities and facilities. Several schemes have been initiated which include Urban Community Development (UCD), Integrated Development of Small and Medium Towns (IDSMT), Environmental Improvement of Urban Slums (EIUS), and Urban Basic Services Program (UBSP). The programme EIUS provided slums covered under the survey with urban basic services. This in fact provided de facto tenure status to the slum dweller. However, this was not adequate for them to be able to access credit from formal housing finance institutions. More recently, as a public-private partnership project, Ahmedabad Municipal Corporation with the participation of a private Corporate body (Arvind Mills) an NGO (SAATH), and the community, implemented a successful slum upgradation project in Sanjay Nagar of Ahmedabad. The project incorporated physical as well as community development objectives. There are several such isolated success stories of slum improvement projects in cities of Gujarat. However, expanding the success to the city level has not been possible till date. Presently the Ahmedabad Municipal Corporation is implementing Slum networking project in 20 of the 2000 odd slum areas in the city.

Recognizing the significance of the problem in urban areas, the state has initiated formulation of a State Slum Policy. The state of Gujarat is the first state to take such an initiative. The effort, being under taken with the World Bank assistance, considers provision of tenure and basic services as major ingredients of the proposed policy. A series of community consultations are underway.

\section{Land Delivery Mechanism}

Land related policies and programmes have a much larger implication on shelter provision for urban household in general and urban poor in specific. These aspects may be broadly categorised as two interdependent set of activities. The first relates to various activities pertaining to land servicing. The second set of activities relate to various set of regulatory practices. These have been briefly analysed below.

\subsection{Land Servicing Mechanisms}

Delivery of urban land implies supplies of serviced land for shelter and related activity development. The process of land servicing includes formal conversion of land from agricultural use to non-agricultural use, preparation of Urban Development Plans (DP) and provision of infrastructure at the macro level. This is followed by preparation of lay out plans/detailed area plans known as Town Planning Schemes (TPS), provision of micro infrastructure and construction of houses (Mittal, 2014, 2013). Regulatory aspects, such as Development Control Rules and Building Byelaws are specified in the DP and the TPS process is governed by the Town Planning Act. Both DP and the TPS reserve land for housing for EWS. The line agencies, GHB and Urban Local Bodies, acquire land under Land Acquisition Act and develop housing schemes through finance from HUDCO.

The TPS mechanism is uniquely democratic and prevalent in the states of Gujarat and Maharashtra. This full cost recovery land readjustment mechanism is a major tool used for the purpose of macro servicing of land. 
However, in the past, the formal supply of land through TPS mechanism has been substantially low as compared to the requirements. The current rate of annual land servicing through TPS is estimated to be 1000 hectares as against the requirement of 3500 hectares (CEPT \& UD \& UH, 2000). Slow pace of land servicing, high cost of land and development plan processing and other imperfections in the land market has led the developers to go beyond the urban development area for undertaking construction activities. During the period 1991 to 1995, in Gujarat, on an average, annually about 3800 to 4300 hectares of land is converted to non-agricultural purposes. Of this 80 to 85 percent of is located in Panchayat areas, which are outside the Urban Planning administrative areas. Due to slow pace of land development the development precedes planning and results into leap-frogging and haphazard development in the peri-urban areas. The state needs to prepare about 30 to 35 schemes per year to meet with the overall land servicing requirements. The pace of completion of TPS preparation needs expedition for which the state has recently amended the Act to expedite the process (Mittal, 2014).

As per the Town Planning Act, up to 10 percent of the TPS land area may be reserved for EWS housing. However, formal supply is limited to 4 to 6 percent of TPS area. The land thus reserved under TPS for weaker section housing is handed over to line agencies which in turn build and allot housing for eligible groups. It is disheartening to note that a tool with significant potential to improve land access to poor has not been utilized to its fullest extent. As stated earlier, if the state prepares about 30 to 35 TPS per year and reserves full 10 percent of the land area, as provided in the Act for weaker section housing, additional land requirements by this section can be met with adequately.

\subsection{Regulatory Provisions}

Most states have wide ranging legislation and regulatory practices related to land development. These include permissions for non-agriculture use, a no objection certificate or exemption from urban land ceiling administration, rules for registration of land transaction, stamp duties on land transfers, approval of layout and subdivisions and building plans, and several clearances from different local agencies for specific purposes. In Gujarat, a total of 13 legislative instruments intervene in the process of land development. The Bombay Land Revenue Code of 1879, The Land Acquisition Act of 1894, Urban Land Ceiling and Regulation Act (1976), The Gujarat Town Planning and Urban Development Act (1976) The Gujarat Municipalities Act (1965), The Bombay Provincial Municipal Corporation Act (1949), The Rent Control Act (1947), The Income Tax Act and Stamp Duty Act are some of the key regulations determining access to urban land in Gujarat. The time and costs involved in following the procedures set by these (both official and unofficial), makes it difficult for the applicant to find ways and means to by pass these. As noted by Mehta, D. and Mehta, M. (1991) "the overall effect of this regulatory regime has created thriving 'unofficial' land market, where transactions are not registered or prices are underreported. This often leads to haphazard growth, where a more planned growth could have been possible. It also creates problems of 'Illegality', in using property as collateral, and in turn makes financing of land development difficult. It also further encourages the process of political patronage and 'clientalism'. In order to overcome these, it is important to evolve simple, flexible and affordable regulations as well as incentives and sanctions to promote equitable land market.”

\subsection{Repeal of ULCRA}

The housing sector has also seen another significant development in the form of repeal of the Urban Land Ceiling and Regulation Act (ULCRA) of 1976 in Gujarat. The main objective of this Act was to impose a limit on possession of vacant land in urban areas to release surplus land for development, including housing for the EWS of the society. However, even after years of implementation, out of 406,282 applications registered for excess vacant land, only 260,281 were finalized. Out of 220,556 hectares of vacant land determined to be excess land, 47,506 hectares have been vested in the state government, out of which possession of only 16,647 hectares has been taken. The extent of excess land for which physical possession has been taken actually, works out to be about 7 per cent of the estimated excess vacant land. (Garg, 1999 as quoted in Acharya, 2000) The provisions of the Act also created artificial scarcity of land, leapfrogging and distorting the urban form (Tiwari, 1999). The repeal of the Act is expected to boost housing construction activity, besides giving a fillip to other sectors such as industry and infrastructure. Since Gujarat repealed the ULC Act, nearly 3000 hectares of serviced land in larger cities of Gujarat has come in market for urban use. 


\section{Housing Finance Mechanism}

Housing finance stands as the single largest financial liability for most of the lower income households. An outlay of INRS 1082 crores $^{8}$ has been made with an annual outlay of INRS. 344.5 crores for housing sector in Gujarat state (GOG, 2000). The per capita annual income in Gujarat is INRS. 13,932 (at 1996-1997 current prices, NSS) and this makes it all the more critical as affordability is low. The cost of a smallest house for economically weaker section (EWS) as determined by Government is INRS. 50,000.

Finance for housing is mobilized through both formal and informal markets in India (Basu \& Mehta, 1993). The formal financial system comprises of financial institutions such as apex housing finance institutions-National Housing Bank (NHB), Housing and Urban Development Corporation (HUDCO), Life Insurance Corporation (LIC) of India, network of housing finance companies (HFCs) like Housing Development and Finance Corporation (HDFC) in the private sector and cooperative housing finance societies. These systems mobilizes resources from budgetary allocations of the central and state Government through general financial institutions such as LIC, General Insurance Company (GIC), commercial banks, provident funds, capital market and deposits. In the recent years, commercial banks have also increased their lending for housing.

The informal financial system mainly include moneylenders, informal community based savings and credit organizations, friends \& relatives. From these sources, people borrow money in times of crisis and for consumption, social, economic and shelter related needs. In this system people can only borrow small amounts of money, at very exorbitant rate of interests, with short repayment period.

A brief review of these has been presented in this section.

\subsection{National Housing Bank (NHB)}

The National Housing Bank (NHB) was created in 1988 as a wholly owned subsidiary of the Reserve Bank of India (RBI) as a Development Finance Institution. The aim was to develop guidelines and directions for the private housing finance corporations, which proliferated during the gradual process of liberalization of the financial market. The mission includes promotion of a market oriented housing finance system, mobilization of additional funds for lending for housing, and supervision and regulation of housing finance institutions. NHB, using the network of Housing Finance Institutions, through refinance mechanism, augments the flow of credit. NHB, from time to time issues norms to regulate HFC's and conducts regular inspections (Stuyketal. 1991).

\subsection{Housing and Urban Development Corporation (HUDCO)}

HUDCO, a Government of India enterprise was established in 1970 under the Companies Act as a public-sector techno-financial institution for housing. HUDCO holds a mandate for providing 30 per cent of its total funds to the EWS housing and 25 per cent to the LIG housing. HUDCO has so far not only financed social housing schemes but also other schemes aimed at provision of basic community facilities and infrastructure HUDCO generally provides bulk loans to State Governments, Housing Boards, Slum Clearance/Improvement Boards, Development Authorities, Improvement Trusts, Municipal Corporations and other local bodies for housing and urban development. HUDCO also finances private developers on the condition that a specified portion of housing is built for weaker sections. Recently HUDCO has started retail housing finance in the country and has made significant impact in the housing finance sector with its low interest rates and consumer friendly dealing.

\subsection{Life Insurance Corporation (LIC)}

LIC, fully owned by the Government of India, also provides long term funds for the state housing boards. As per the statute, LIC is required to invest at least of its net accretions to its funds to bonds and debentures of HUDCO, State Housing Boards and other "Socially Oriented Schemes”. LIC also provides retail housing finance.

\subsection{Housing Finance Companies (HFCs)}

The last decade has seen the emergence of a credible housing finance system in India, with a number of housing finance companies (HFCs) providing finance through an expanding retail network. The total number of HFCs has grown from 30 in 1988 to 367 in 1997 (NHB). Most have followed the successful pioneering model pro-

\footnotetext{
${ }^{8} 1$ Crore is 10 million.
} 
vided by the HDFC. These institutions largely cater to the need of middle and upper income groups.

\subsection{Housing Development Finance Corporation (HDFC)}

HDFC, though classified as HFC, has a performed pioneer role in the development of housing finance sector. HDFC set up as a private housing finance institution in 1977 under the Companies Act, caters to the shelter-related needs of individuals, co-operative societies and companies. Lately, HDFC has also started focusing on providing shelter finance to the weaker sections of the population. As noted by Acharya (2000), HDFC's low-cost housing schemes are marked by the emphasis on peoples' participation and usage of self-help approach wherein the beneficiaries contribute both in terms of cash and labor for construction of their houses. HDFC collaborates with both Government and non-governmental organizations (NGOs).

\subsection{NGO Initiatives in Housing Finance}

The involvement of NGOs in housing finance has become increasingly significant during the past decade. They are involved either as part of lending and savings programmes for micro enterprises or as with their involvement in poverty reduction strategies (Mongia, 1996). The NGO involvement appears facilitate the poor by ensuring better functioning of financial markets for the low-income groups. Some of the other successful initiatives at national and international level include: SEWA, Rastriya Gramin Vikas Nidhi (RGVN), SHARE from India, GRAMEEN BANK-Bangladesh, Community Mortgage Programme (CMP)-Philippines.

In the context of India, though these efforts are limited in their coverage, both in terms of number of people they serve and geographical areas they cover, they definitely contribute in terms of possible approaches to provide credit to the low-income households. Inspired by some of these work, National Bank for Agriculture and Rural Development (NABARD) through the network of Nationalized Banks in collaboration with NGOs, has initiated nationwide programme of formation and strengthening of Self Help Groups (SHGs) in rural areas. The objective is to promote people owned and controlled decentralized savings linked credit mechanism and through that increase the flow of institutional finances for low-income households in rural areas.

Similarly, in urban areas initiatives are being taken by organizations to address the credit needs of the poor. These efforts include setting up of self-help groups; mainly of women members of the communities and through these groups provide credit to address crisis \& consumption, shelter \& basic services and economic needs. Though compared to the total needs these efforts are inadequate, they do show the possibilities for the future direction. SEWA bank in Ahmedabad and SPARC in association with National Federation of Slum Dwellers and Mahila Milan in Bombay are some of the efforts in the direction.

\subsection{Limitations of the Current Financial System}

While institutions like NHB, HUDCO and HDFC have been able to mobilize resources and attract sizable number of individuals and households to the housing sector; their contribution to total housing finance is estimated at only about 10 percent. Around $3 / 4^{\text {th }}$ of the housing finance needs in India are serviced by the informal sector (Khan 1998 as quoted by (Nair, 1999).

HFI's such as HDFC and NHB have not effectively addressed the housing finance needs of the potential borrowers from low income households, as the chief criteria of these institutions for providing finance is the monthly household income from formal sources. The repayment capacity of a loan seeker is judged from education level and proof of last few years' consistent income. The property papers are kept as collateral till the repayment is complete. The earnings from informal sources and inconsistent income of the poor do not provide consistent income proof and limits their access to the formal housing finance system.

Thus low income households, both in urban and rural areas are not adequately integrated within the formal credit system of the country. Nationalized Banks and formal Financial Institutions, though having mandate, money and mechanism to provide credit to all, have largely remained inaccessible to the poorer sections of our society.

A physical and more importantly psychological distance between the lending institutions and borrowers from low-income households combined with lack of appropriate operating systems to address the credit needs of the poor is evident.

In past, the efforts to force nationalized banks to provide credit to poor have not yielded desired results. Contrary to the expectations, the process has further alienated banks from the poor and ruined the credibility of both, 
banks and borrowers. As a result, for banks the issue of credit to the poor has largely remained a matter of fulfilling a social obligation rather than a business proposition.

The ever widening gap between those who need credit and those institutions which have financial resources, has been forcing low income households to increasingly depend on informal financial system, for their various credit needs.

On the other hand in the informal financial system, the smaller loan amounts and higher rates of interest, (some times as high as 10 percent per month from the money lenders as against 1 percent per month from Banks) reduces their chances of generating surplus and eventually break free from the cycle of poverty and deprivation.

It is necessary to explore the linkages between the financial institutions and low-income households such that on one hand it increases the access of low-income households to the much-needed credit from the formal financial system and on the other maintain the financial discipline and health of the lending organizations.

It is realized that an institution that could combine the strengths of an NGO and the expertise of a financial institution, with participation from the community, would be appropriate in meeting the housing and credit needs of the participating community.

\section{Future Directions}

The issues in urban housing revolve around three operational areas i.e. Housing, Land and Finance. The focus should be on enabling access to housing rather than delivering a product. This would mean change in approach where poor are perceived as resource and not a liability and problem of slums is a systemic one, needing systemic response. Following are some thoughts in the possible future directions.

\subsection{Housing}

The past experience of the state as a housing provider has not been as effective as planned and hence needs to change. The governments increasingly should become a promoter and not a provider.

Along with creating enabling policy environment, the role of the government as provider for the poorest of the poor should continue to remain. However there is need to rethink the approach by seeking to initiate systemic responses rather than implementing projects. This may include creating support systems and infrastructure which integrates urban poor in the physical and economic fabric of the urban centres.

The policy issues including Development Permission procedures, Norms and Standards, especially for lowincome settlements, Rent Control needs to be re-examined and simplified.

\subsection{Land}

With regard to land, slow pace of supply of serviced land is a critical concern (HSMI, 1992; USAID, 1988). In the prevailing process due to delays the development precedes planning defeating the objective of planned growth and development.

To overcome this, two measures may be useful. It is seen that at least major portion of the time goes in seeking administrative approvals from several departments and layers of the government. It may be useful to create one window clearance system at local government level. Secondly, establish effective land information system, especially with respect to land records in areas likely to be urbanized would also help in reducing time delays. Coupled with this, simplification of permission procedures, which are cumbersome and resource consuming, redefining the norms and standards are also to be evolved.

While the above measures would enhance the pace of land servicing, the issue of land to the poor still remain. As discussed, the poor is faced with multi pronged problems and hence the strategies have to address these in a comprehensive manner. Two basic issues need to be addressed with regard to access of land to poor. The first relates to the way in which the problem of existing slums is to be tackled. The second relates to access of land to the newly entering urban poor.

The first issue of existing slums largely revolves around tenure, services and finance. Clear-cut evidences exist to show that provision of tenure to households brings in social and economic stability as well as investments and improvements in housing. However, the modalities are not simple. The policy would have to seriously consider awarding tenure rights to the slum dweller, though at reasonable cost. This, in addition to acknowledging their existence and self-respect, would also enable them to access housing finance for housing upgradation. 
Though, awarding tenure to all those on publicly held land may be just an administrative action and is possible to commit with exceptions of land reserved for roads and in locations which are unsafe for habitation like river beds, tank beds etc. There is also a significant portion of slum development on private land. Given the fact that these have been in existence for decades, use of "Transfer of Development Rights", "Land Sharing Technique" or "micro-level Town Planning Scheme" would enable governments to access these lands and subsequently transfer the same to the poor. More details on Land readjustment mechanism and how they could be used in developing large scale infrastructure projects area available in Mittal (2014, 2013).

However, these strategies would have to be evolved after a series of stakeholder consultations as part of ongoing preparation of State Slum Policy for the economically and socially disadvantaged.

For the second category of urban poor, who are in migrating a different strategy needs to be evolved. The poor who enter at this level first needs a place to work and than a place to live. The need for accommodation is transitory in nature before they consolidate their stay in the urban areas. A support system to receive such influx of people and facilitate smooth transition in to the urban system needs to be institutionalized. The ideas like reception centres combined with vocational training cum employment placement services can be explored.

\subsection{Housing Finance}

With increasing numbers of shelter-less urban poor, the demand for housing finance is rising consistently. Pulley, (1989) has stated that the sustained access to credit contributes positive income gains that gradually shift poor households over the poverty line. Till now, the models experimented by HFCs to provide credits to the poor are either provision of direct credit to the poor or route the same through NGOs. Both these approaches have not effectively utilized the comparative strengths of the three principal stakeholders and have essentially treated the poor as beneficiaries, NGOs as conduits and Formal Financial Institutions (FFIs) as fund provider.

In these approaches, the problem is one of inadequate understanding of the FFIs about the socio-economic conditions of the poor. Further, the NGOs have been seen as a financial intermediary rather than a facilitator of linking borrower and bankers.

The proposed model attempts to overcome these limitations of the present system by creating a partnership where all the three stakeholders have financial stakes and management role in sustenance and strengthening of financing mechanism.

It is proposed to setup a Micro Finance Intermediary (MFI) with equity being brought in by FFIs, partnering NGO and the community. The core function of MFI will be to mobilize and augment funds to CBOs on the basis of their performance of mobilization of savings and recovery of credit. The role of MFI apart from linking finances will also be to provide non-financial support in terms of efficient management of micro level credit and capacity building of community based organizations.

The MFI in the present system are facing multitude of problems due to Governance system imposed by the prevailing Banking laws. These need to be reviewed in view of special socio-economic characteristics of the poor. The legal structure needs to foster flexibility and innovations to address the credit needs of the poor while maintaining financial discipline required running sustainable financial institutions.

\section{Conclusion}

The role of the Government should be one of promoter rather than a provider, through creating conducive environment and facilitating servicing of land. Access to serviced land at an affordable price could be provided through establishing effective land information management system. There is an urgent need to simplify multiple layers of legal and administrative procedures in land approvals maintaining the necessary requirement.

The experience of Grameen Bank, Bangladesh and Sewa Bank, India has shown that the poor and the needy are able to and willing to pay for quality housing if there is an institutional support to provide access to credit. Hence, the economically weaker section needs to be integrated with the formal financial system through MFI with the involvement of FFI's, NGO's and CBO's where all three stakeholders have financial and managerial stakes. Authors envisage this as a sustainable model for continuing housing support systems for urban Gujarat, India, where both the essential needs of access of land and credit to the low income families are provided.

\section{References}

Acharya, S. (2000). Paper on Housing Finance in India. Ahmadbad: CEPT. 
Basu, D. N., \& Mehta, V.K. (1993). Housing Finance System in India-As It Was and as It Is Emerging. New Delhi: Ministry of Urban Development, NIUA, Government of India.

Bertrand, R. (1991). Housing Reforms in Socialist Economies. World Bank Discussion Paper 125, Washington DC: The World Bank.

Census of India (2001). Provisional Census Tables. New Delhi: Government of India.

CEPT \& UD \& UH (CEPT and Urban Development \& Urban Housing Department) (2000). Base Paper on Urban Housing. Gandhinagar: Government of Gujarat.

Directorate of Economics \& Statistics, Government of Gujarat (1999). Socio-Economic Review. Gandhinagar: Government of Gujarat. Budget Publication No. 30

General Administrative Department, Government of Gujarat (2000). Development Programme (2000-2001). Gandhinagar: Government of Gujarat, Budget Publication No. 31.

GSDMA (Gujarat State Disaster Management Authority) (2001). Fact Sheets. Gandhinagar. http://www.gsdma.org/factsright.htm

Gujarat Social Infrastructure Development Board (2000) Human Development Vision 2010. Gandhinagar: Government of India.

HSMI (1992). Access of the Poor to Urban Land. New Delhi: HSMI.

Lall, V. D. (1996). Assessment of Housing Need. In National Housing Seminar, Technical Session No. 1. New Delhi: Society for Development Studies.

Mehta, D. and Mehta, M. (1991) Land for Shelter, Delivery of Serviced land in Metropolitan Areas (Vol.1-Summary and Policy Decisions). Ahmedabad: CEPT.

Mehta, D. and Mehta, M. (1989). Housing Finance Systems in Metropolitan Areas in India. Ahmedabad: CEPT.

Mittal, J. (2014). Self-Financing Land and Urban Development via Land Readjustment and Value Capture. Habitat International, 44, 314-323.

Mittal, J. (2013). Extending Land Readjustment Schemes to Regional Scale: A Case of Regional Ring Road via Mosaicking Neighborhood Level Plans. Real Estate Finance Journal, 30, 62-73.

Mongia, J. N. (1996). Role of Government, NGO’s, CBO’s and Other Stakeholders in the Housing Sector. In National Housing Seminar-Adequate Shelter for All, Technical Session No. 6. New Delhi: Socio Economic Research Foundation.

Nair, T. S. (1999). Housing: The Missing Concern. In Economic and Political Weekly (pp. 1871-1872).

Pulley, R. V. (1989). Making the Poor Creditworthy. World Bank Discussion Paper 58, Washington DC: The World Bank.

Renauld, B. (1991). Housing Reforms in Socialist Economies. World Bank Discussion Paper 125, Washington DC: The World Bank.

Stuyk, R., Ferguson, B., \& Ravicz, M. (1991). Market Oriented Housing Finance in India: The National Housing Bank's First Two Years. Urban Institute: USAID.

Swamy, S. (2001). Urban Health Mapping. Ammadabad: CEPT, GMFB.

Tiwari, A. (1999). Impact of ULCRA on Land and Real Estate Market of Ahmedabad. Unpublished Dissertation, Ahmedabad: School of Planning, CEPT.

USAID (1988). An Urban/Shelter Strategy for India-Draft 1. New Delhi: USAID.

http://www.sdsindia.org/policy.htm 


\section{Annexure 1: Data Tables-Urbanization Trends}

Annexure 1. (a) Urban population in Gujarat 1971-2021 (projected); (b) Urban population growth rates 1971-2021 (projected); (c) Urban population share 1971-2021 (projected); (d) Trends in household size.

\begin{tabular}{ccccccc}
\hline Urban Area Type & $\mathbf{1 9 7 1}$ & $\mathbf{1 9 8 1}$ & $\mathbf{1 9 9 1}$ & $\mathbf{2 0 0 1}$ & $\mathbf{2 0 1 1}$ & $\mathbf{2 0 2 1}$ \\
\hline M.C./Agglomeration & 3456236 & 5277824 & 7399351 & 10547121 & 15026785 & 21212228 \\
Class-A Municipalities & 753998 & 1017692 & 1393178 & 1886556 & 2552268 & 3492908 \\
Class-B Municipalities & 1265420 & 1662021 & 2465688 & 3399306 & 4685659 & 6484315 \\
Class-C Municipalities & 743589 & 940565 & 1168625 & 1504026 & 1922011 & 2543997 \\
Class-D Municipalities & 458755 & 612319 & 698812 & 891165 & 1126415 & 1481530 \\
Others & 634861 & 916120 & 1429865 & 2076867 & 3011833 & 4297543 \\
Total & 7312859 & 10426541 & 14555519 & 20305040 & 28324971 & 39512521 \\
\hline
\end{tabular}

(a)

\begin{tabular}{cccccc}
\hline \multirow{2}{*}{ Urban Area Type } & \multicolumn{5}{c}{ Growth Rate (percent) } \\
\cline { 2 - 6 } & $\mathbf{1 9 7 1 - 8 1}$ & $\mathbf{1 9 8 1 - 9 1}$ & $\mathbf{1 9 9 1 - 0 1}$ & $\mathbf{2 0 0 1 - 2 0 1 1}$ & $\mathbf{2 0 1 1 - 2 1}$ \\
\hline M.C./Agglomeration & 4.32 & 3.44 & 3.61 & 3.60 & 3.51 \\
Class-A Municipalities & 3.04 & 3.19 & 3.08 & 3.07 & 3.19 \\
Class-B Municipalities & 2.76 & 4.02 & 3.26 & 3.26 & 3.30 \\
Class-C Municipalities & 2.38 & 2.19 & 2.56 & 2.48 & 2.84 \\
Class-D Municipalities & 2.93 & 1.33 & 2.46 & 2.37 & 2.78 \\
Others & 3.74 & 4.55 & 3.80 & 3.79 & 3.62 \\
Total & 3.61 & 3.39 & 3.39 & 3.38 & 3.38 \\
\hline
\end{tabular}

(b)

\begin{tabular}{ccccccc}
\hline \multirow{2}{*}{ Urban Area Type } & \multicolumn{5}{c}{ Share of State's Urban population (percent) } \\
\cline { 2 - 7 } & $\mathbf{1 9 7 1}$ & $\mathbf{1 9 8 1}$ & $\mathbf{1 9 9 1}$ & $\mathbf{2 0 0 1}$ & $\mathbf{2 0 1 1}$ & $\mathbf{2 0 2 1}$ \\
\hline M.C./Agglomeration & 47.26 & 50.62 & 50.84 & 51.94 & 53.53 & 53.05 \\
Class-A Municipalities & 10.31 & 9.76 & 9.57 & 9.29 & 9.09 & 9.01 \\
Class-B Municipalities & 17.30 & 15.94 & 16.94 & 16.74 & 16.69 & 16.54 \\
Class-C Municipalities & 10.17 & 9.02 & 8.03 & 7.41 & 6.85 & 6.79 \\
Class-D Municipalities & 6.27 & 5.87 & 4.80 & 4.39 & 4.01 & 3.98 \\
Others & 8.68 & 8.79 & 9.82 & 10.23 & 10.73 & 10.63 \\
Total & 100.00 & 100.00 & 100.00 & 100.00 & 100.89 & 100.00 \\
\hline
\end{tabular}

(c)

\begin{tabular}{|c|c|c|c|c|c|c|}
\hline \multirow{2}{*}{ Urban Area Type } & \multicolumn{6}{|c|}{ Average Household Size } \\
\hline & 1971 & 1981 & 1991 & 2001 & 2011 & 2021 \\
\hline M. C./Agglomeration & 5.58 & 5.55 & 6.23 & 6 & 5.90 & 5.50 \\
\hline Class-A Municipalities & 5.51 & 6.03 & 5.40 & 5.35 & 5.35 & 5.30 \\
\hline Class-B Municipalities & 5.38 & 5.62 & 5.39 & 5.3 & 5.30 & 5.30 \\
\hline Class-C Municipalities & 5.36 & 5.66 & 5.53 & 5.5 & 5.40 & 5.35 \\
\hline Class-D Municipalities & 5.06 & 5.40 & 5.15 & 5.15 & 5.10 & 5.00 \\
\hline Others & 5.25 & 5.51 & 5.35 & 5.3 & 5.30 & 5.30 \\
\hline
\end{tabular}

Source: May 2000, base paper on housing, CEPT \& UD \& UH (CEPT \& UD \& UH, 2000).

(d) 


\section{Annexure 2: Data Tables-Land and Housing}

Annexure 2. (a) Land approved for non-agricultural purposes in Gujarat (percentage); (b) Land approved as N.A. in urban and Panchayat areas of Gujarat; (c) Annual land requirement for urban Gujarat by use (in Ha.); (d) Slum households in municipal corporations (percentage); (e) Distribution of slum households located on public and private land (percent); (f) Housing requirements present and projected; (g) Investment in housing in India in public and private sectors through five-year plans.

\begin{tabular}{cccccccc}
\hline Purpose/Year & $\mathbf{1 9 8 8 - 8 9}$ & $\mathbf{1 9 9 0 - 9 1}$ & $\mathbf{1 9 9 1 - 9 2}$ & $\mathbf{1 9 9 2 - 9 3}$ & $\mathbf{1 9 9 3 - 9 4}$ & $\mathbf{1 9 9 4 - 9 5}$ & Total \\
\hline Residential & 56.4 & 57.7 & 54.3 & 50.5 & 44.6 & 36.8 & 42.5 \\
\hline Commercial & 34.0 & 15.3 & 17.9 & 24.1 & 28.2 & 14.5 & 37.2 \\
\hline Industrial & 9.6 & 27.0 & 27.8 & 25.4 & 27.2 & 48.7 & 20.3 \\
\hline Total & 100.0 & 100.0 & 100.0 & 100.0 & 100.0 & 100.0 & 100.0 \\
\hline Total land area (Ha) & 6294 & 4285 & 3787 & 3190 & 3289 & 3850 & 36216 \\
\hline
\end{tabular}

Note: Data for 1989-90 appear erroneous and therefore are not included. Source: Based on data available from government of Gujarat, Gandhinagar.

(a)

\begin{tabular}{cccccccc}
\hline Land/Year & $\mathbf{1 9 8 8 - 8 9}$ & $\mathbf{1 9 9 0 - 9 1}$ & $\mathbf{1 9 9 1 - 9 2}$ & $\mathbf{1 9 9 2 - 9 3}$ & $\mathbf{1 9 9 3 - 9 4}$ & $\mathbf{1 9 9 4 - 9 5}$ & Total 1988 to 1995 \\
\hline Urban & 33.5 & 21.0 & 9.7 & 23.8 & 13.4 & 13.1 & 15.4 \\
Panchayat & 66.5 & 79.0 & 90.3 & 76.2 & 86.6 & 86.9 & 84.6 \\
Total & 100.00 & 100.0 & 100.0 & 100.0 & 100.00 & 100.00 & 100.00 \\
Total land area (in Ha) & $(6294)$ & $(4285)$ & $(3787)$ & $(3190)$ & $(3289)$ & $(3850)$ & $(36216)$ \\
\hline
\end{tabular}

Note: Data for 1989-90 appear erroneous and therefore are not included. Source: Government of Gujarat, Gandhinagar.

(b)

\begin{tabular}{ccccc}
\hline Year & Total Requirement & $\begin{array}{c}\text { Requirement } \\
\text { for Housing }\end{array}$ & $\begin{array}{c}\text { Requirement for } \\
\text { Commercial use }\end{array}$ & $\begin{array}{c}\text { Requirement for } \\
\text { Industrial Use }\end{array}$ \\
\hline $1991-2001$ & 1835 & 618 & 50 & 154 \\
$2001-2011$ & 2287 & 771 & 62 & 192 \\
\hline
\end{tabular}

Source: May 2000, base paper on housing, CEPT \& UD \& UH (CEPT \& UD \& UH, 2000).

(c)

\begin{tabular}{cccc}
\hline Urban area & $\mathbf{1 9 7 3}$ & $\mathbf{1 9 8 3}$ & $\mathbf{1 9 9 0}$ \\
\hline Ahmedabad & 22.80 & 23.9 & 24.90 \\
Bhavnagar & 13.24 & 14.9 & 16.18 \\
Jamnagar & 31.20 & 24.6 & 20.82 \\
Rajkot & 9.57 & 16.4 & 23.90 \\
Surat & 23.10 & 24.1 & 24.80 \\
Vadodara & 13.10 & 13.8 & 14.31 \\
\hline
\end{tabular}

Source: Mehta, M., \& Mehta, D. (1990) Housing Strategies for the Eight Plan: A Perspective for Gujarat State. Ahmedabad: CEPT. School of Planning.

(d)

\begin{tabular}{ccc}
\hline Urban area & \multicolumn{2}{c}{ Proportion of hh's living in slums, 1990 } \\
\cline { 2 - 3 } & Government land & Private land \\
\hline Ahmedabad & 55 & 45 \\
Bhavnagar & 79 & 21 \\
Jamnagar & 46 & 54 \\
Rajkot & 81 & 19 \\
Surat & 62 & 38 \\
Vadodara & 95 & 5 \\
\hline
\end{tabular}

Source: Mehta, M., \& Mehta, D. (1990) Housing Strategies for the Eight Plan: A Perspective for Gujarat State. Ahmedabad: CEPT. School of Planning.

(e) 


\begin{tabular}{lcccc}
\hline Year & Urban Population & Total Households & Housing Need & Additional Requirement \\
\hline 1991 & $14,246,061$ & $2,673,960$ & $2,922,869$ & - \\
2001 & $18,835,351$ & $3,671,608$ & $4,166,174$ & $1,287,148$ \\
2011 & $24,555,141$ & $4,995,960$ & $5,618,955$ & $1,515,274$ \\
\hline
\end{tabular}

Source: May 2000, base paper on housing, CEPT \& UD \& UH (CEPT \& UD \& UH, 2000).

(f)

\begin{tabular}{cccc}
\hline Plan period & \multicolumn{3}{c}{ Investment in Housing (in INRS. million) } \\
\hline First Plan & $2,500(22)$ & Private & Total \\
Second Plan & $3,000(23)$ & $9,000(78)$ & $11,500(100)$ \\
Third Plan & $4,250(27)$ & $10,000(77)$ & $13,000(100)$ \\
Fourth Plan & $6,250(22)$ & $11,250(73)$ & $15,500(100)$ \\
Fifth Plan & $10,440(22)$ & $21,750(78)$ & $28,000(100)$ \\
Sixth Plan & $14,910(11)$ & $36,360(78)$ & $46,800(100)$ \\
Seventh Plan & $24,580 \quad(9)$ & $1,15,000(89)$ & $1,29,910(100)$ \\
Eighth Plan & 35,817 & $2,90,000(91)$ & $3,14,580(100)$ \\
\hline
\end{tabular}

Source: Planning commission as quoted in (Suresh 1999b). Note: Figures in parentheses indicate percentages.

(g) 
Scientific Research Publishing (SCIRP) is one of the largest Open Access journal publishers. It is currently publishing more than 200 open access, online, peer-reviewed journals covering a wide range of academic disciplines. SCIRP serves the worldwide academic communities and contributes to the progress and application of science with its publication.

Other selected journals from SCIRP are listed as below. Submit your manuscript to us via either submit@scirp.org or Online Submission Portal.
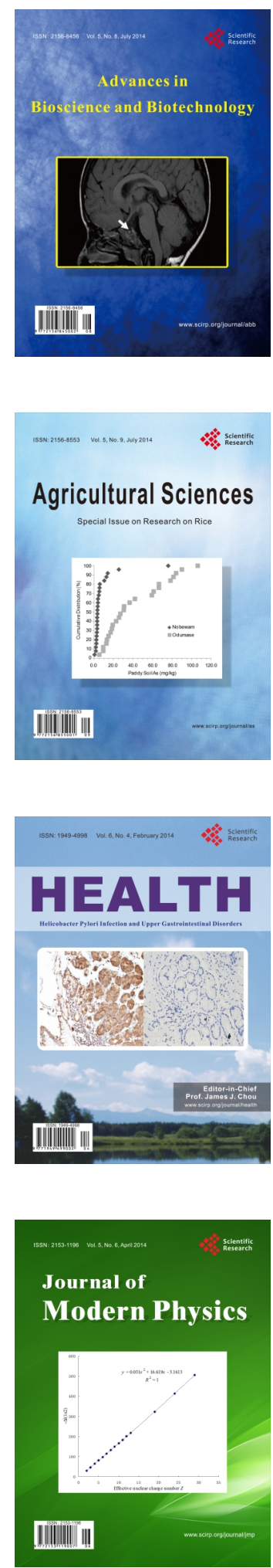
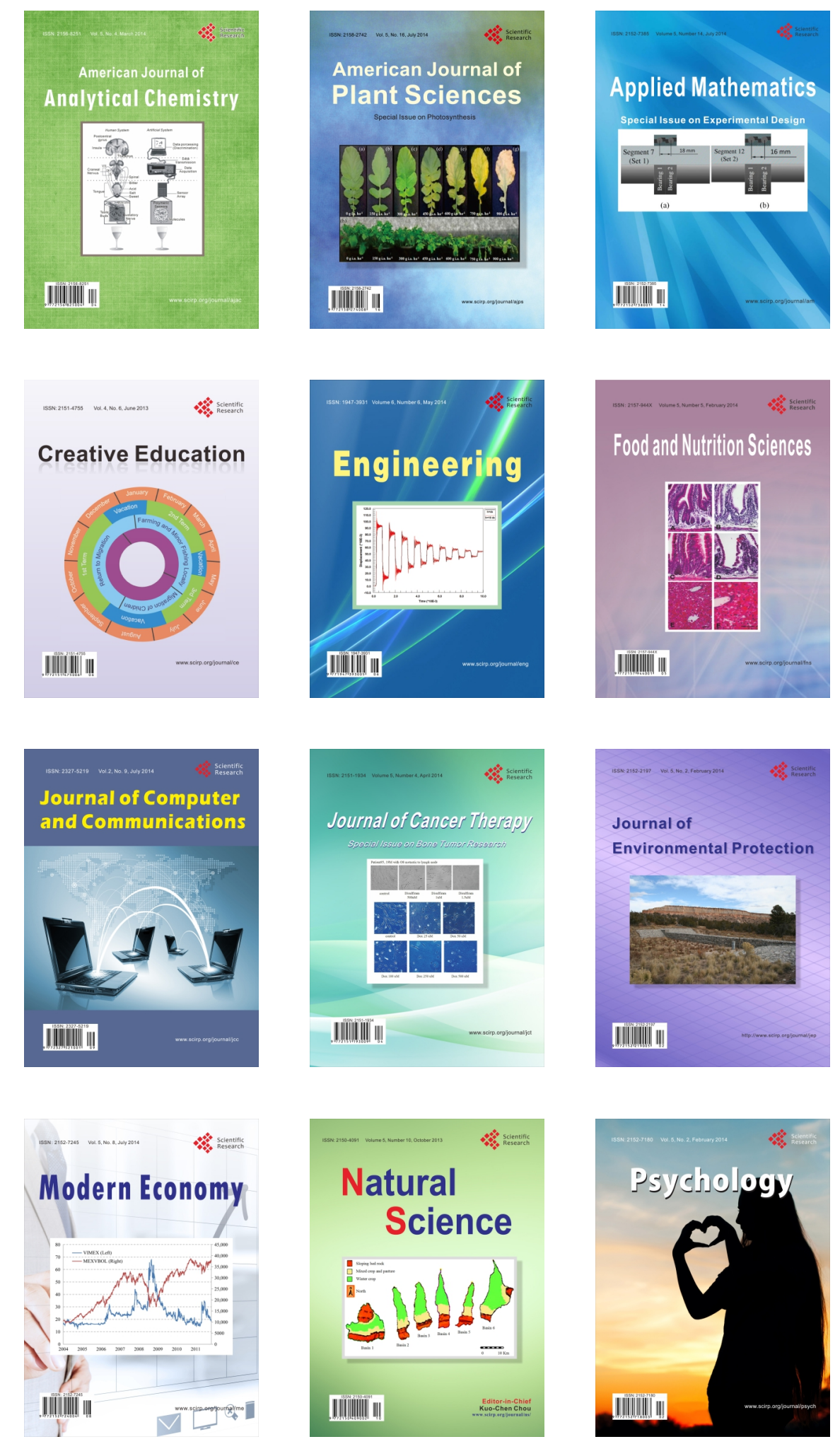